\title{
Meningkatkan Kesiapan Siswa TK Yaa Bunayya Lodoyo Untuk Menerapkan "New Normal Life" Pada Pandemi Covid 19
}

\author{
Ning Arti Wulandari ${ }^{1 *}$, Anita Rahmawati ${ }^{2}$, Yeni Kartika Sari ${ }^{3}$ \\ ${ }^{I}$ STIKes Patria Husada Blitar, Jl.Sudanco Supriyadi 168 Kota Blitar \\ ${ }^{2}$ STIKes Patria Husada Blitar, Jl.Sudanco Supriyadi 168 Kota Blitar \\ ${ }^{3}$ STIKes Patria Husada Blitar, Jl.Sudanco Supriyadi 168 Kota Blitar \\ Email:ningarti83@gmail.com
}

\begin{abstract}
Abstrak
Pandemi covid-19 yang terjadi di dunia termasuk Indonesia mendorong pemerintah untuk menghimbau masyarakat menerapkan kebiasaan normal baru sebagai langkah pencegahan penularan covid 19. Masyarakat khususnya orangtua dan siswa TK Yaa Bunayya Lodoyo masih belum mempunyai pengetahuan dan perilaku yang optimal untuk pencegahan penularan covid-19. Pengabdian kepada masyarakat ini bertujuan untuk meningkatkan kesiapan siswa TK Yaa Bunayya Lodoyo untuk menerapkan "new normal life" melalui peningkatan pengetahuan orang tua dan siswa dalam mencegah penularan covid 19. Kegiatan pengabdian berupa pemberian edukasi dalam 2 tahap, tahap pertama dengan metode ceramah kepada orangtua dan tahap kedua edukasi dengan media video yang diberikan kepada siswa. Kegiatan ini diikuti oleh 27 orangtua/walisiswa dan 51 siswa TK Yaa Bunayya Lodoyo. Pengumpulan data menggunakan kuesioner dan data dianalisis dengan uji statistik paired t-test. Hasil Pengabdian menunjukkan bahwa pengetahuan orangtua dan perilaku siswa mengalami peningkatan yang signifikan.
\end{abstract}

Kata kunci: covid-19;siswa; new normal life

\section{Abstract}

The covid-19 pandemic that occurred in the world, including Indonesia, encouraged the government to urge people to adopt new normal habits as a measure to prevent the transmission of covid 19. The community, especially parents and students of Yaa Bunayya Lodoyo Kindergarten, still do not have optimal knowledge and behavior to prevent Covid19 transmission. This community service aims to improve the readiness of TK Yaa Bunayya Lodoyo students to implement "new normal life" by increasing the knowledge of parents and students in preventing Covid 19 transmission. the second stage of education with video media provided to students. This activity was attended by 27 parents / guardians and 51 TK Yaa Bunayya Lodoyo students. The data were collected using a questionnaire and the data were analyzed using the paired t-test statistical test. Service results show that parents' knowledge and student behavior have increased significantly.

Keyword: covid-19; students;new normal life

\section{PENDAHULUAN}

\section{Corona Virus Disease awa}

kemunculannya berasal dari kota Wuhan

Cina pada akhir tahun 2019, kemudian

diberi nama Severe Acute Respiratory

Syndrome Coronavirus 2 (SARS-COV2),

dan menyebabkan penyakit Coronavirus
Disease-2019 (COVID-19). Menurut WHO (2019) Corona virus merupakan keluarga besar virus yang menyebabkan penyakit pada manusia dan hewan. Pada manusia biasanya menyebabkan penyakit infeksi saluran pernapasan, mulai flu biasa hingga penyakit yang serius seperti Middle East Respiratory Syndrome 
(MERS) dan Sindrom Pernafasan Akut

Berat/ Severe Acute Respiratory Syndrome (SARS) (Azis, 2020). Jawa

Timur menduduki peringkat ke 3 kasus corona virus dengan jumlah 4857 jiwa (Kemenkes RI, 2020). social distancing, menggunakan masker, cuci tangan dan menjaga imunitas tubuh merupakan cara yang direkomendasikan untuk mencegah penularan covid 19. Pemerintah Indonesia menghimbau masyarakat untuk membatasi kegiatan yang tidak penting, meliburkan sekolah dan menghimbau sekolah untuk melaksanakan pembelajaran secara daring untuk meminimalkan penularan covid 19 pada anak dan pembelajaran tatap muka diperbolehkan untuk zona hijau dan zona kuning, Namun pembelajaran daring berpotensi menimbulkan dampak negatif yang berkepanjangan. Adapun dampak negatif tersebut antara lain; ancaman putus sekolah, penurunan capaian belajar dan kekerasan pada anak dan resiko eksternal sehingga kemendikbud telah membuat kebijakan baru di bulan Agustus 2020, bahwa pendidikan anak usia dini akan dimulai paling cepat 2 bulan setelah jenjang pendidikan dasar dan menengah (Kemendikbud, 2020). Anak usia pra sekolah merupakan kelompok umur yang rentan terhadap penularan covid 19, sehingga perlu upaya untuk meningkatkan pencegahan penularan covid 19 pada kelompok umur tersebut. Di AS kematian anak usia 1-4 tahun akibat covid 19 adalah 3 dari 95.608 sedangkan anak usia 5-14 tahun 13 dari 95.608. Kondisi pandemi seperti saat ini perlu dipastikan keamanan untuk membuka kembali sekolah dengan cara mengkaji kembali kejadian covid 19 di daerah tersebut memberikan informasi tentang manfaat dari menjaga jarak, kebersihan dan penggunaan masker dilingkungan sekolah (Sten H Vermund and Virginia E Pitzer, 2020). Sehingga meningkatkan perilaku anak usia pra sekolah untuk mencegah penularan covid 19 dengan perilaku hidup bersih sehat yang baru untuk tetap bisa berdampingan dengan covid 19, media sosial menyebutnya sebagai new normal life, oleh sebab itu perlu dipersiapkan secara khusus, terutama menyiapkan perilaku hidup bersih sehat untuk mencegah penularan covid 19 pada peserta didik terutama anak usia pra sekolah. Berdasarkan latar belakang diatas pengabdi ingin memberikan keberdayaan pengetahuan, ketrampilan melalui edukasi pencegahan penularan covid 19 kepada orang tua dan anak pra sekolah untuk meningkatkan kesiapan new normal life

\section{GAMBARAN UMUM , PERMASALAHAN DAN SOLUSI MASYARAKAT SASARAN.}

Sasaran utama pengabdian ini adalah kelompok masyarakat non produktif yaitu walimurid dari siswa TK Yaa Bunayya Lodoyo TK Yaa Bunayya Lodoyo 
merupakan, lembaga pendidikan anak usia pra sekolah yang dikelola oleh yayasan. Jumlah total anak didik dari kelas PAUD sampai dengan TK Besar 62 orang, 10 guru pendamping dan 1 orang petugas kebersihan. Berdasarkan survey didapatkan yang dilakukan dengan beberapa wali murid melalui daring dari 10 siswa, 6 orang merasa tidak nyaman menggunakan masker, 8 orang tidak pernah membersihkan handphonenya, 8 orang juga tidak menghindari kerumunan dan bersalaman jika bertemu teman atau kerabat, semuanya mempunyai anak yang tidak pernah mau menggunakan masker ketika keluar rumah dan hanya mau menggunakan face shield saja. Seluruh orang tua siswa yang diwawancarai mengatakan belum pernah mendapatkan edukasi, mengatakan bahwa ketika orang tua mengambil workshet mingguan ke sekolah selalu mengajak anaknya, dan beberapa tidak menggunakan masker dengan alasan tidak mau. Selain itu tampak di para wali murid masih berkumpul dengan wali murid yang lain di luar sekolah. Informasi yang disampaikan oleh kepala sekolah dinas bahwa pendidikan perilaku hidup bersih sehat baru untuk mencegah penularan covid 19 telah masuk kurikulum pembelajaran namun pelatihan khusus atau edukasi dari tenaga kesehatan secara langsung tentang perilaku hidup bersih sehat pencegahan covid 19 masih belum ada. Menurut Lismanda, Y. F (2017) peran orang tua dalam keluarga secara teratur dan aktif dapat meningkatkan perilaku pada anak. meningkatkan perilaku pencegahan penularan covid 19 pada anak usia pra sekolah, dan saat ini sedang pembelajaran dirumah. keterlibatan orang tua sangatlah penting dalam proses edukasi sekaligus role model dirumah, pengabdi mengawali edukasi kepada orang tua,

\section{METODE}

Metode pada pelaksanaan pengabdian masyarakat menggunakan pendekatan edukasi yang dilakukan sebagai upaya meningkatkan perilaku pencegahan penularan covid 19 pada orang tua dan anak usia pra sekolah untuk menghadapi "new normal life" di TK Yaa Bunayya Lodoyo, dilakukan dengan dua tahap kegiatan. Tahap pertama pengabdi memberikan edukasi secara langsung dengan metode ceramah. Jumlah populasi sebagai sasaran dari kegiatan pengabdian ini sebanyak 62 orang tua siswa, namun yang hadir sebanyak 27 orang

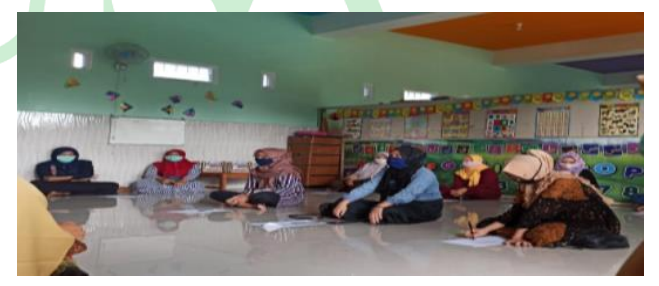

Gambar 1. Peserta edukasi tahap pertama 
Pelaksanaan kegiatan tahap satu dilaksanakan di aula TK Yaa Bunayya Lodoyo bertepatan dengan kegiatan sosialisasi pembelajaran tahun akademik 2019/2020 yang diadakan oleh sekolah, Waktu pelaksanaan pada 9 Juli 2020, proses pelaksanaan menggunakan protokol kesehatan, orang tua siswa wajib menggunakan masker, tidak mempunyai suhu lebih dari 38 derajat celcius, mencuci tangan sebelum masuk ruangan dan menjaga jarak saat edukasi berlangsung. Tahap dua merupakan edukasi kepada anak usia pra sekolah yang dilakukan dengan media video melalui daring. Video edukasi tersebut berjudul "Neca Is My Hero" terbagi menjadi 7 episode yang di tayangkan satu episode setiap minggunya sesuai dengan program pengajaran yang di buat oleh sekolah. Adapun materi yang disampaikan di dalam video tersebut antara lain memperkenalkan tokoh yang ada dalam video tersebut, cuci tangan 6 langkah, menggunakan alat perlindungan diri yang benar jika keluar rumah, menjaga jarak dengan teman, cara batuk dan bersin yang benar, pentingnya makan sayur dan buah dan olah raga serta berjemur. Video edukasi tersebut ditayangkan melalui chanel youtube
Pengabmas STIKes PHB 2020. Pengabdi memberikan link youtube tersebut kepada guru, kemudian guru mengirim ke group whatsapp kelas. Untuk memastikan bahwa video tersebut dilihat oleh orang tua dan anak, guru memberikan penugasan kepada orang tua untuk memfasilitasi anak menirukan kegiatan pencegahan penularan covid 19 sesuai dengan video yang dilihatnya dan mendokumentasikannya kemudian dikirim kepada guru kelas masingmasing.

\section{HASIL DAN PEMBAHASAN}

Pelaksanaan edukasi untuk meningkatkan kesiapan siswa TK Yaa Bunayya Lodoyo untuk menghadapi "new normal life" pada pandemi Covid-19 berjalan sesuai dengan yang direncanakan. Edukasi tahap pertama yang dilaksanakan secara langsung diikuti oleh 27 orangtua.

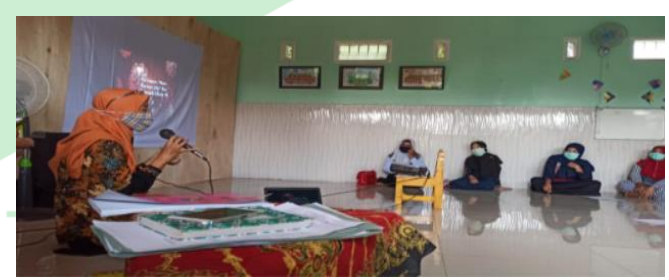

Gambar 2 Kegiatan Edukasi Tahap Pertama Di Aula TK Yaa Bunayya Lodoyo

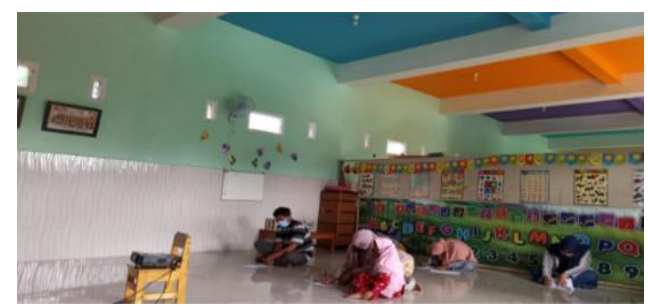

Gambar 3 Pengisian Kuesioner Pretest 
Hasil pretest dan posttest pengetahuan orangtua terlihat pada tabel 1 .

Tabel 1. Hasil nilai pengetahuan orangtua pretest dan posttest Edukasi kesiapan siswa untuk menghadapi "New Normal Life"

\begin{tabular}{lllll}
\hline Nilai & Mean & Min. & Max. & t-test \\
\hline pretest & 7.2 & 7.0 & 9.0 & \\
posttest & 9.8 & 9.0 & 10.0 & 0.000 \\
\hline
\end{tabular}

Sebelum dilakukan edukasi, pengetahuan orangtua dalam mencegah penularan covid-19 atau dalam menerapkan perilaku "new normal life" masih belum optimal terlihat dari tabel 1 diatas, nilai rata-rata pengetahuan orangtua sebelum edukasi 7.2 (nilai total tertinggi 10). Setelah dilakukan edukasi, semua nilai pengetahuan orangtua meningkat dengan nilai rata-rata 9.8 . Berdasarkan hasil analisis statistik dengan menggunakan paired t-test menunjukkan ada perbedaan yang signifikan nilai pengetahuan orangtua sebelum dan setelah dilakukan edukasi. Pelaksanaan edukasi pada tahap kedua diberikan kepada seluruh siswa TK Yaa Bunayya Lodoyo secara daring, terdapat 51 siswa yang mengikuti pengukuran perilaku. pretest dan posttest dimana pengukuran perilaku anak dilakukan oleh orangtua/wali siswa masing-masing menggunakan kuesioner. Hasil pengukuran perilaku anak tersebut terlihat pada tabel 2.
Tabel 2. Hasil Nilai Perilaku Anak Pretest Dan Posttest Edukasi Kesiapan Siswa Untuk Menghadapi "new normal life"

\begin{tabular}{lllll}
\hline Nilai & Mean & Min. & Max. & t-test \\
\hline pretest & 13.1 & 8.0 & 17.0 & \\
posttest & 22.7 & 9.0 & 28.0 & 0.000
\end{tabular}

Berdasarkan tabel 2 terlihat bahwa perilaku anak dalam pencegahan penularan covid-19 atau dalam penerapan "new normal life" mengalami peningkatan dari rata-rata nilai sebelum edukasi 13.1 menjadi 22.7 setelah diberikan edukasi melalui video daring. Analisis dengan menggunakan paired t-test juga menunjukkan perbedaan yang signifikan perilaku anak sebelum dan setelah diberikan edukasi.

Metode pembelajaran PAUD/TK disesuaikan dengan kebutuhan dan karakteristik perkembangan anak yang belajar melalui benda nyata sehingga media audiovisual lebih menarik untuk anak karena memiliki gambar bergerak, suara dan alur cerita (Muthmainnah, 2015). Video yang digunakan sebagai media edukasi pada tahap kedua dalam kegiatan pengabdian ini diberikan kepada siswa TK sehingga dikemas dengan cerita yang menarik, bahasa yang mudah diingat dan dimengerti oleh anak TK sehingga mampu meningkatkan perilaku anak menerapkan kebiasaan normal baru dalam mencegah penularan covid 19. Peningkatan perilaku anak juga 
dipengaruhi oleh peran orangtua. Orangtua yang mempunyai pengetahuan atau tingkat pendidikan yang lebih tinggi dapat menunjukkan peran orangtua yang baik dalam pendidikan anak usia dini (Novrinda et al., 2017).

Dalam kegiatan pengabdian ini, edukasi tahap pertama diberikan kepada orangtua untuk menyiapkan pengetahuan orangtua. Metode ini berperan dalam mengubah persepsi mal adaptif, perilaku menjadi persepsi yang adaptif sehingga mampu berperan dalam meningkatkan kesiapan anak menghadapi new normal life (Masita, Elly Dwi, 2018)

Komunikasi antara orang tua dan anak meningkatakan kedekatan sehi

ngga anak cenderung mengikuti semua perilaku orang tua. (Kelly, 2012; Okeke, 2014). Komunikasi orang tua membangun kedekatan sehingga anak cenderung mengikuti apapun perintah orang tua dan menirunya Masita \& Amalia, n.d. (2018) Pemberlakuan pembelajaran dirumah seperti di masa pandemi covid 19 ini membuat anak lebih banyak dirumah dan lebih dekat dengan orangtua sehingga peran orang tua dalam meningkatkan kesiapan perilaku pencegahan penularan covid 19 lebih besar dibanding guru.

\section{KESIMPULAN DAN SARAN}

Kegiatan pengabdian kepada masyarakat berupa pendekatan edukasi untuk meningkatkan kesiapan siswa untuk menghadapi "new normal life" pada pandemi Covid-19 di TK Yaa Bunayya Lodoyo menghasilkan kesimpulan yaitu; (1) Pendekatan edukasi pada orangtua/wali siswa meningkatkan keberdayaan pengetahuan tentang kesiapan new normal life dengan indikator nilai rata-rata pre test sebesar 7.2. menjadi 9.8 setelah diberikan edukasi. Pendekatan edukasi ketrampilan melalui video dapat mengubah nilai rata- rata perilaku dari 13.1 menjadi 22.7. Berdasarkan hasil kegiatan ini kami menyarankan kepada orang tua tetap mengajarkan kepada anak-anak perilaku pencegahan penularan covid 19. Sedangkan saran untuk guru adalah untuk tetap memberikan motivasi kepada anak didiknya untuk tetap melakukan perilaku pencegahan penularan covid 19 dan menyiapkan sarana, prasarana dan metode pembelajaran langsung di era pandemi covid 19 (Cubaka et al., 2018; Kallem et al., 2013; Stiekema et al., 2018)

\section{REFERENSI}

Azis, S. (2020, March 30). Why 'physical distancing' is better than 'social distancing'. Retrieved April 30, 2020, from aljazeera.com https://www.aljazeera.com/new s/2020/03/physical-distancingsocial-distancing200330143325112.html

Cubaka, V. K., Schriver, M., Cotton, P., Nyirazinyoye, L., \& Kallestrup, P. (2018). Providers' perceptions of communication with patients in primary healthcare in Rwanda. Plos 
One, 13(4), e0195269. https://doi.org/10.1371/journal.pon e.0195269

Kallem, S., Carroll-Scott, A., GilstadHayden, K., Peters, S. M., McCaslin, C., \& Ickovics, J. R. (2013). Children's Report of Lifestyle Counseling Differs by BMI Status. Childhood Obesity, 9(3), 216-222. https://doi.org/10.1089/chi.2012.01 00

Kelly, M. (2012). The influence of context and ecology on children's development. Journal of Community Nursing, 26(2).

Kemendikbud. (2020). Penyesuaian Keputusan Bersama Empat Menteri tentang Panduan Pembelajaran di Masa Pandemi COVID-19. Kemendikbud.

Kemenkes RI. (2020). Covid-19 dalam Angka. Kemenkes RI.

Lismanda, Y. F. (2017). PONDASI PERKEMBANGAN

PSIKOSOSIAL ANAK

MELALUI PERAN AYAH DALAM KELUARGA. Vicratina Jurnal Pendidikan Islam, 2(2), 89-98. http://riset.unisma.ac.id/index.p hp/fai/article/view/826

Masita, Elly Dwi, S. M. (2018). IMPLEMENTASI TRIPLE C PARENTING PADA PENGASUH ANAK YANG MENGALAMI OBESITAS DINI USIA 3-5 TAHUN DI PAUD RW III KELURAHAN WONOKROMO. Community Development Journal, 2(2), $377=379$. https://doi.org/https://doi.org/10.33 086/cdj.v2i2.630

Masita, E. D., \& Amalia, R. (n.d.). MODUL TRIPLE-C PARENTING
(E. D. Masita (ed.)).2018.Surabaya:Unusapress

Muthmainnah, -. (2015). Pemanfaatan Video Clip Untuk Meningkatkan Keterampilan Sosial Anak Usia Dini. Jurnal Pendidikan Anak, 2(2), 372-381.

https://doi.org/10.21831/jpa.v2i2.3 050

Novrinda, N., K., \& Yulidesni. (2017). Peran Orangtua dalam pendidikan anak usia dini ditinjau dari latar belakang pendidikan. Jurnal Potensia, 2(1), 1-8.

Okeke, C. I. (2014). Effective homeschool partnership: Some strategies to help strengthen parental involvement. South African Journal of Education, 34(3). https://doi.org/10.15700/20140916 1044

Stiekema, A., vanderMeer, L., Looijmans, A., Corpeleijn, E., Bruggeman, R., Jörg, F., \& Schoevers, R. (2018). Effects of a lifestyle intervention on psychosocial well-being of severe mentally ill residential patients: ELIPS, a cluster randomized controlled pragmatic trial. Schizophrenia Research, 199. https://doi.org/10.1016/j.schres.20 18.02 .053

Sten $H$ Vermund and Virginia E Pitzer. 2020. Asymptomatic Transmission and the Infection Fatality Risk for COVID-19: Implications for School Reopening. Clinical Infectious Diseases.

https://academic.oup.com/cid/a dvancearticle/doi/10.1093/cid/ci aa855/5862668 